\title{
COLONIAL RACIAL ETHNOCENTRISM TOWARDS INDIGENOUS PEOPLE IN A SHORT STORY COLLECTION "SEMUA UNTUK HINDIA" BY IKSAKA BANU (A POSTCOLONIAL STUDY)
}

\author{
Nensilianti ${ }^{1}$, Sy. Fatma Al-Khiyyed ${ }^{2, *}$, Hasvivi Tri Anjarsari Fahrir ${ }^{3}$ \\ ${ }^{1}$ Department of Languages and Literature, Faculty of Language and Literature, Universitas Negeri Makassar, \\ Makassar 90221, Indonesia \\ ${ }^{2}$ Department of Languages and Literature, Faculty of Language and Literature, Universitas Negeri Makassar, \\ Makassar 90221, Indonesia \\ ${ }^{3}$ Department of Languages and Literature, Faculty of Language and Literature, Universitas Negeri Makassar, \\ Makassar 90221, Indonesia
}

\section{ARTICLE INFO}

Keywords:

All for Hindia

Colonialism

Indigenous people

Racial ethnocentrism

Article History:

Received: 19/11/2020

Accepted: 17/05/2021

Available Online:

31/05/2021

\begin{abstract}
A B S T RACT
Dutch colonialism in Indonesia brought about physical oppression and conquest of territory and instilled racism. Understanding racism positions the indigenous people as a third class whose rank has never been higher than the Dutch. Racial ethnocentrism leads people to concepts and views of life that consider their culture to be far superior to the culture owned by others. This study aimed to reveal and describe the forms of racial ethnocentrism brought by the Dutch towards Indonesian society. The data were obtained from excerpts or quotes that contain elements of racism from a short story collection "Semua untuk Hindia (All for Hindia)" by Iksaka Banu. The analysis results revealed that racial ethnocentrism or racism emerged in racial prejudice, stereotypes, and discrimination in the short story collection. The cultivation of these ethnocentric behaviors was based on the Western cultural concept and view of ideal human beings and the human position passed down from generation to generation. It impacted the Dutch's social construction and use of authority in oppressing the indigenous people in Indonesia. Indigenous figures were oppressed, marginalized, and their human rights were ignored. Research on the short story collection can strengthen the disclosure of colonialism history in Indonesia.
\end{abstract}

2442-305X / (C) 2021 The Authors, this is open access article under the (CC-BY-NC) license (https://creativecommons.org/licenses/by-nc/4.0/), DOI: 10.19105/ojbs.v15i1.3982

\footnotetext{
$\bar{*}$ Corresponding Author:

Email address: syarifahfatma09@gmail_com (S. F. Al-Khiyyed)
}

\section{A. Introduction}

The dark history of Indonesia, which was dominated by colonialism, is well recorded. The concept of race as a derivative of understanding identity, physicality, and ethnicity favors one particular group over another, based on one's genetics.

The racism echoed by the colonials became a polemic during and after the 
colonial rule in Indonesia. Identity is something of great concern because the concentration and general concept of respect depend on where a person comes from and their color.

Such classification leads to the justification of all forms of racism. ${ }^{1}$ Related to colonial superiority against indigenous peoples in terms of race and ethnicity in almost all parts of the world made the race even more intense. Racism was also used as a driving force to legalize all forms of oppression under Dutch colonial rule. The Netherlands positioned Indonesian society as a third-class society which was referred to as inlander or indigenous. $^{2}$ The grouping of natives and their genuine differences in treatment were based on Dutch political and ideological interests. In addition to conquering the Colonial territory, the Dutch also inserted and instilled an understanding and the view that indigenous peoples' culture was only of low value that could never match the Dutch's. This attitude made some people feel intensely oppressed and eventually try to accept the understanding of racism. ${ }^{3}$

\footnotetext{
${ }^{1}$ Mudji Sutrisno, Cultural Studies: Tantangan Bagi Teori-Teori Besar Kebudayaan (Depok: Penerbit Koekoesan, 2011), 133.

2 Iswadi Bahardur, "Pribumi Subaltern dalam NovelNovel Indonesia Pascakolonial," Gramatika: Jurnal Penelitian Bahasa dan Sastra 4, no. 1 (2017): 89100, https://doi.org/10.22202/jg.2017.v3i1.1876; Sulistianawati, "Pribumi Subaltern dalam Novel Lampuki Karya Arafat Nur (Kajian Poskolonial Gayatri C. Spivak)," Stilistika: Jurnal Pendidikan Bahasa dan Sastra 13, no. 2 (2020): 155-67, https://doi.org/10.30651/st.v13i2.4533.

${ }^{3}$ Bahardur, "Pribumi Subaltern dalam Novel-Novel Indonesia Pascakolonial," 100.
}

Ethnocentrism leads a nation to a concept and a way of life that assumes that its culture is far superior to other cultures. The nation then sees and judges a culture from the perspective of its own culture. $^{4}$

Racial ethnocentrism dissolves into harmful stereotypes and hostile behavior shown to individuals outside the group and loyal to fellow group members of the same race. The people believe that they have the right to dominate other races considered inferior.

The community's social identity makes certain groups see themselves as more positive and superior than others. This belief in superiority is maintained from generation to generation by certain races. This crucial point then becomes a dark record of the world throughout history and a big point of human atrocities in the past. The great agenda has been fought for a long time ago. Many parties remember the events and perpetuate them in various media. Along with the times, memories of Western colonialism's traces, not only just present but were also born in the form of texts called literary works. ${ }^{5}$

Literary works that record messages of the world become a never-ending forum for discussing dark memories from the

\footnotetext{
4 Deddy Mulyana and Jalaluddin Rakhmat, Komunikasi Antar Budaya: Panduan Berkomunikasi dengan Orang-Orang Berbeda (Bandung: Remaja Rosdakarya, 2010), 76-77.

5 Nensilianti and Dian Hezedila Sharon, "Novel Entitle Student Hidjo by Mas Marco Kartodikromo: Postcolonial Study," in International Conference on Natural and Social Sciences (ICONSS) Proceeding Series 1, vol. 2, 2019, 375-81, https://doi.org/10.30605/iconss.57.
} 
postcolonial era. Literary works with colonialism and Western racist behavior in the colonized areas can still be found. The writers convey various thoughts and realities in their works from time to time. These thoughts come and go to fill the space where human curiosity and tendencies reside. Every literary work is born to tell a story through various processes and forms. One of them is the short story, such as a collection of short stories created by Iksaka Banu entitled Semua untuk Hindia (All for Hindia).

The symptoms included in a literary work are social images that the author then translates into the literary work itself. These symptoms usually occur and are experienced by the community or may have occurred in the author's own life. Similarly, everything in the world is transformed by the author into a piece of literature. $^{6}$

Semua untuk Hindia is a collection of short stories by Iksaka Banu set in the nation's colonial history. The thirteen stories in this collection of short stories are based on stories from before the arrival of Cornelius de Houtman until the early days of Indonesian independence. Each short story tells about Indonesian history from a diverse and distinctive perspective. Unlike the previous fictional

\footnotetext{
6 Taguh Alif Nurhuda and Herman J Waluyo Suwitno, "Pemanfaatan Sastra Sebagai Bahan Ajar Pengajaran BIPA," in The 1st Education and Language International Conference Proceedings Center for International Language Development of Unissula. Halaman (The 1st Education and Language International Conference Proceedings Center for International Language Development of Unissula, 2017), 864-69.
}

prose, which revolves around colonialism, such as Salah Asuhan and Nyai Dasimah, which place the native figure as the main character who lives in Dutch style and is Dutch-style, most of the short stories from this collection of short stories place the Dutch figure as the main character of the story.

The placement of the Dutch character as the main character of the story gives the impression that the colonial point of view dominates the point of view used in this collection of short stories. Thus, the collection of short stories, All for the Indies, shows a different side in seeing the colonizers and their lives than historical fiction books in general. Besides, with the placement of a central figure that tends to be different from the characterizations in general, the writer tries to present a different side of the colonial world which is rarely explored. The short stories tell the story of the colony's daily life and reveal things that are sometimes put aside to be listened to even though they have essential values. The placement of the Dutch protagonists' stories in this collection of short stories indicates that the writer tried to put himself in a neutral position that did not side with the colonialists or the colonies. However, besides that, it still emphasizes colonialism as it is full of ethnocentric understanding.

Iksaka Banu is a graphic designer and worked in the advertising industry in Jakarta. His work has been featured in a variety of Indonesian mass media. Semua untuk Hindia is a collection of short stories that the author wrote between 2006 and 
2014. The author wanted to highlight different events and figures in history and compel his readers to look at history from different perspectives. As a result, he brought this book to the level with brilliant ideas. In 2008 and 2009, he won Pena Kencana Awards, and in 2014 his collection of short stories titled "Semua Untuk Hindia" won Khatulistiwa Literary Award.

The characters in the story are like spirits that cannot be separated from the colonial era. Journalists, soldiers, administrators, and Nyai (Miss) are depicted as historical eyes and ears that become the symbols of the colonialism practices and impacts on society.

The stories in this collection of short stories lead readers back to the colonialism era that left traces in various corners of Indonesia. The events in this short story collection feature heroes of independence and critical Dutch figures who have had a significant portion in the history of colonialism at that time. The characters in these stories, be they from the Colonials or the Subalterns, are depicted through dramatic dialogues to reveal the neat and detailed plans and efforts of the colonialists in hegemonizing and executing colonial practices in the Dutch East Indies.

Research on racial ethnocentrism is mainly carried out with different objects of study. For example, Carignan et al. applied racial ethnocentrism studies in education to study how identity recognition was formed in a multicultural and intercultural perspective. ${ }^{7}$ Long before this research, Martin examined the decision to give the nickname beautiful among white men and black men who were influenced by superior and superior races using the concept of racial ethnocentrism. ${ }^{8}$ William Cunningham et al. discuss white racial ethnocentrism towards a black society manifested in implicit and explicit attitudes. ${ }^{9}$ Hall's dissertation emphasized that racial ethnocentrism powerfully shapes racial identities among American-Indian ethnicities. ${ }^{10}$ Permatasari et al. examined the negative impact of ethnocentrism by analyzing data films and found that ethnocentrism resulted in a more substantial building of belief in the superiority of one's own culture than other cultures. ${ }^{11}$

\footnotetext{
${ }^{7}$ Nicole Carignan, Michael Sanders, and Roland G. Pourdavood, "Racism and Ethnocentrism: Social Representations of Preservice Teachers in the Context of Multi- and Intercultural Education," The International Journal of Qualitative Methods 4, no. 3 (2005): $1-19$, https://doi.org/10.1177/160940690500400301.

8 James G. Martin, "Racial Ethnocentrism and Judgment of Beauty," The Journal of Social Psychology 63, no. 1 (1964): 59-63, https://doi.org/10.1080/00224545.1964.9922213.

9 William A. Cunningham, John B. Nezlek, and Mahzarin R. Banaji, "Implicit and Explicit Ethnocentrism: Revisiting the Ideologies of Prejudice," Personality and Social Psychology Bulletin 30, no. 10 (2004): 1332-46, https://doi.org/10.1177/0146167204264654.

${ }^{10}$ Schekeva Hall, "The Role of Racial Socialization and Ethnocentrism in the Racial Identity Development of Second-Generation Black West Indian Americans" (Doctoral Dissertation, Columbia University, 2012), 88, https://academiccommons.columbia.edu/doi/10.791 6/D8RVOVTK.

11 Riana Permatasari, "The Negative Effects of Ethnocentrism in My Big Fat Greek Wedding Movie," Jurnal Penelitian Humaniora 20, no. 2
} 
Analysis of racial ethnocentrism in fictional stories related to the colonial era seems scarce, especially those examining the impact of racial ethnocentrism on subaltern societies. Therefore, this research was conducted to reveal how the colonizers built a racist identity in their colony by analyzing Ishaku Banu's short stories, Semua untuk Hinda. The specific objectives of this article are to (1) analyze the forms of racism that the colonialists made against indigenous peoples, and (2) how racial ethnocentrism had an impact on the indigenous population.

\section{B. Method}

This research was designed using a qualitative approach which is presented descriptively. In applying this research design, the researcher is also a key instrument. The data of this research are quotations in short stories that contain the form and impact of racial ethnocentrism. This data is sourced from the book Semua untuk Hindia by Iksaka Banu, which contains thirteen short stories with a book thickness of 176 pages. The Popular Gramedia Library first published this collection of short stories in $2014 .^{12}$

Nine short stories were selected as the primary source of data for this research, namely: "Stambul Dua Pedang", "Keringat dan Susu", "Racun untuk Tuan", “Gudang Nomor 012B”, "Semua untuk Hindia", "Tangan Ratu Adir", "Di Ujung Belati", "Penunjuk Jalan", and "Mawar di

(2019):

89-97,

https://doi.org/10.23917/humaniora.v20i2.7401.

12 Iksaka Banu, Semua untuk Hindia (Jakarta: Kepustakaan Populer Gramedia, 2018).
Kanal Macan." The nine short stories are told through various views of characters who are typical as historical witnesses, ranging from journalists, former soldiers, plantation workers, and a Nyai. The Dutch dominated the main characters of the short stories.

The research data were analyzed using content analysis techniques through data reduction, data analysis presentation, and conclusion drawing. The data analysis process was carried out using the postcolonial theory of Frantz Fanon, which views race as something essential in the colonial process. From this concept, racial ethnocentrism emerges from racial ethnocentrism in racial prejudice, stereotypes, and discrimination, which impact division and alienation.

\section{Results}

\section{Racial Ethnocentrism}

Racial ethnocentrism occurs in various cognitive forms that give birth to ramifications such as racial prejudice, discrimination, and stereotypes. Fanon said that one of the characteristics of colonialism is the endless case of racism. ${ }^{13}$ European people with racist behavior believed in their countries spread racism to their colonies and make it an absolute thing in their colonies. ${ }^{14}$ Their actions, in the end, will damage the mental, psychological, and order of life of

13 Frantz Fanon, Black Skin, White Masks: Kolonialisme, Rasisme, Psikologi Kulit Hitam, trans. Harris H Setiadji (Yogyakarta: Jalasutra, 2016), viii.

${ }^{14}$ Marilyn Lake, "Equality and Exclusion: The Racial Constitution of Colonial Liberalism," Thesis Eleven 95, no. 1 (2008): 20-32, https://doi.org/10.1177/0725513608095798. 
the indigenous people. These ethnocentric behaviors are observed in the stories in Semua untuk Hindia by Iksaka Banu.

\section{a. Racial Prejudice}

Racial prejudice refers to a cultural perspective and the Western's view of the concept and position of the ideal human being passed down from generation to generation. The West gives racial prejudice to everyone outside their race. This prejudice invites a vigilant attitude towards natives. In the history of colonialization in various civilizations, prejudice was allocated to the indigenous peoples who were colonized (subaltern societies).

These prejudices are generally tolerated and spread within the same community groups to foster similar actions and attitudes towards the inferior community. ${ }^{15}$ According to Fanon, being a native means having to be constantly watched and alerted because, for the invaders, anything can happen from the minds of the natives, and all bad possibilities will always haunt them. ${ }^{16}$

In Semua untuk Hindia by Iksaka Banu, several parts mark racial ethnocentrism in the form of racial prejudice. Racial prejudice is illustrated through a speech delivered to the public. The colonialists demonstrated this ethnocentric behavior towards Indonesian society, in this case, a colonized society.

${ }^{15}$ Rupert Brown, Prejudice: Its Social Psychology (London: Wiley-Blackwell, 2011), 13.

${ }^{16}$ Fanon, Black Skin, White Masks: Kolonialisme, Rasisme, Psikologi Kulit Hitam, 17.
"Beware of Bumi Putra (the natives); they are full of tricks." ${ }^{17}$

The caution expressed by the Dutch towards these Indigenous people is racial prejudice and a viewpoint that indicates that the Indigenous people are a society full of tricks and violent behavior. Behind the helplessness of the Indigenous people under their colonization, the Dutch believed that the harsh conditions the natives were living in could lead to cunning thoughts in their heads. The Dutch thought that the indigenous people would want to do anything to survive.

The Dutch thought that the Bumiputera or indigenous people could trick them. The Netherlands increasingly believed in this assumption because there were many rogues inhabiting forests foreign to the Dutch. The indigenous people who deeply understood the conditions and environment they lived in would easily harm the Dutch, who were still unfamiliar with the place and the situation.

"But you must remain vigilant," said Mr. Van Zaandam on one occasion. "Once you hurt, at that time, you must be careful of the food and drink they serve." "Pill number 11? arsenic, phenyl, or cobra saliva? I will remember it always." ${ }^{18}$

The presumption of evil behavior is addressed to men and the indigenous women who live with them. Amid conversations about indigenous women who accompanied them to take care of their household and various needs, the Dutchmen continued to spread

${ }^{17}$ Banu, Semua untuk Hindia, 122.

${ }^{18}$ Banu, 43. 
accusations of the cruelty of indigenous women who were considered to have wrong and hurtful behavior. These issues spread widely and became a shared understanding of many Dutchmen who lived and lived with indigenous women.

"Some kids tugged at my clothes or tapped me on the leg while giggling. Very different from their parents, who stood silently. There is a cold aura in their eyes and the curves of their lips."

The Dutch point of view in the data shows an assessment of the evil and unfriendly behavior of the natives. For the Dutch, the Indigenous people who live in remote areas and have not been touched by them are a group of wild and dangerous humans. According to them, these natives would not hesitate to do cruel things to them.

The Dutch saw the Bumiputera as having the ability to survive by tricking people, especially the Dutch. Their views on indigenous men were the same as their views on indigenous women considered cunning. They both saw that they would do various evil things in carrying out their plans.

"These newcomers generally do not have the skills. When the industry goes bankrupt, they roam the streets, increasing the number of bad people." 20

The period of colonialism was marked by human trafficking. The colonialists gathered and brought natives from one area to another to be employed in various fields. Human trafficking was

\footnotetext{
${ }^{19}$ Banu, 124

${ }^{20}$ Banu, 108
}

intended to obtain people who would be used as plantation workers, road workers, factories, and domestic workers in Dutch homes. Not only involving men, but this trade also sold women who were generally made concubines. If the Dutch Lord's business went bankrupt, they would be abandoned or sold back.

The sentence "When the industry goes bankrupt, they roam the streets, increasing the number of bad people" represents the western prejudice that the native people will increase crime on the streets after the industry in which they went bankrupt. This understanding relates that Bumiputera always initiates every crime and thing that challenges the law. Bumiputera is made into a group of groups that will take actions that are detrimental to many people. Such understanding spread not only in Java Island as a significant center of development and colonialism but also widespread throughout the regions where colonialism occurred.

\section{b. Stereotype}

Concerning racial ethnocentrism, colonialists made certain stereotypes about indigenous peoples. The stereotypes then developed into a social construction created based on the colonialists' mindset. This way of thinking then became a persistent perspective.

With the stereotypes that grew up in the colonial environment, colonial society slowly allowed themselves to be poisoned by their stereotypes. They slowly assumed that what the colonials directed 
against them was always right because it was their nature. ${ }^{21}$

"Mijn God. The child and the mother are very, very brown. And, they sleep on my embroidered pillow."22

From the start, the white people clearly showed racism. The culture of slavery that has occurred for several centuries has made this increasingly crucial. Equality between races is impossible to find. White people think that those with skin other than white are dirty and disgusting humans who need to be defined.

The above excerpt depicts the colonialist's disgusted emotion towards the Indigenous people. The statement "Mijn God. The child and the mother are very, very brown" signifies the inferiority of those with brown skin (natives), primarily when they use furniture or household appliances. This "color" stereotype has developed among white people for generations.

Stereotypes about the inferiority of people with brown skin or colored skin have long developed in various parts of the world. White people are reluctant to use things that people of color have used.

"...a Malay woman who became noble after living with men of other nations. Beauty in a golden cage."23

The entire indigenous community is a lowly society. However, when a woman is married to a foreign man, she becomes elevated both socially and economically.

\footnotetext{
${ }^{21}$ Fanon, Black Skin, White Masks: Kolonialisme, Rasisme, Psikologi Kulit Hitam, 93.

${ }^{22}$ Banu, Semua untuk Hindia, 136.

${ }^{23}$ Banu, 18.
}

The above excerpt clearly illustrated that the position of an indigenous woman would be nobler than other indigenous women if she marries a Dutchman. Being a Nyai, although not making the native woman as honorable as a Dutch woman, is still considered more classy and more respectable than other indigenous women. Since A Nyai had lived with the Dutch household customs, she would also be familiar with the typical Dutch manner. This knowledge made a Nyai hold a respectable position in the community.

The house of a Dutchman is a golden cage for native women. These women will be respected as part of the Dutch family even though they will never equal the rank of other Dutch women.

"Why does a kebaya (an Indonesian blouse-dress combination)-and I mean a white kebaya - have more value than another colored kebaya? Is it considered the closest to the European skin color?"24

The excerpt illustrates that all life layers and joints are well-arranged to comply with and follow the pattern formed by the colonialists. A Nyai who had lived with the Dutch Master was required to wear a white kebaya instead of a more colorful kebaya. The white color is associated with the skin color of the colonial race, not the color of the indigenous skin, brown. This culture is passed down from time to time in every family consisting of a Lord and a Nyai.

This speech shows a stereotype that puts forward the idea that white is an appropriate color. It also demonstrates the

${ }^{24}$ Banu, 38. 
status of women who wear a white kebaya higher than those who wear a kebaya with other colors.

The Stereotype about the degree and inferiority of indigenous peoples continues in other respects, as the following excerpt shows.

"We need them to turn the wheels of the economy, but we have to remove trash from the city." ${ }^{25}$

During the colonial period, indigenous people worked as laborers. Indigenous people were used as sources of energy, especially during the development period, to accelerate the economy. However, polemics concerning natives and their work ethic occurred every once in a while. Many of the natives were accused of wrongdoing, rebellion, and other things that the Dutch could not tolerate. As a result, an initiative emerged to eliminate the natives thought to disturb the rate of economic growth and the country's development.

The above excerpt depicts colonialism in conversations containing elements that support the eradication of indigenous peoples.

Despite their need for natives as labor force, the Dutch felt they had a right to the territories inhabited by indigenous peoples. The excerpt contains the word "trash," which denotes a bad nickname addressed to the natives. The colonists intended to remove the "trash" from cities of control that can be found in all regions in Indonesia.

\footnotetext{
${ }^{25}$ Banu, 108.
}

The speech act indicates the suspicion that indigenous people need to be eradicated and ostracized. The use of the word "trash" emphasizes that the existence of the natives is not something essential but rather a burden that can exacerbate the situation. It also points out a stereotype where a community group is humiliated by calling them "trash."

Another stereotype that the author delivers through his stories is shown in the following excerpt.

"Crazy! I am a scholar, Prometheus fireman. Successor to Hippocrates' oath. Dying of nerves in the presence of ambassadors from the darkest aisle of science." 26

Dutch society has always upheld science and academic achievements. Such advanced thinking at that time developed in various western regions, especially in Europe. Unlike Indonesia, as a colony, the Netherlands and other colonial countries had mastered a science that was so difficult to study. Even education centers in Indonesia only provided facilities for a small number of citizens with privileges. Therefore, many Indonesians applied science according to hereditary beliefs, for example, traditional health sciences.

The above excerpt shows that a Dutchman could pride himself as a person with excellent knowledge. Meanwhile, he made the prejudice that the indigenous people had never known knowledge as they had. The statement "the darkest aisle of science" emphasizes the prejudice that the natives are ignorant human beings

${ }^{26}$ Banu, 125 
with no education or knowledge. The following excerpt expresses this prejudice:

"They inherited the face of the Netherlands; they will be fine." ${ }^{27}$

It has become an assumption that the Dutch will always have respect, unlike the Indigenous people. A growing prejudice was that people who inherited a Dutch face would not experience any trouble in all businesses. Through this statement, the Dutch indirectly raised another stereotype that the indigenous people were a society full of problems. The Dutch assumed that the Indigenous people would never achieve things equal to the colonialists. Being an Indigenous meant being a society that had no future and thus was isolated because, in essence, they never progressed and were trapped in ignorance and distress.

These stereotypes have greatly influenced the life and views of the Dutch as well as the Indigenous people. Then, the birth of another stereotype followed, such as shown below:

"Imah, I paused for a moment as if I just realized that I have never called her Dutch name. I guess the name she used to say suited her better than Maria Goretti Aachenbach." ${ }^{28}$

A native woman would never give up her identity as a native even though she had undergone deep polishment, and their name was no exception. Despite marrying a Dutchman, a native woman would not automatically change into a Dutch woman. She would remain a native, no matter how high the status and power the husband had.

In the end, a Nyai would leave the house when their husband married a Dutch woman. She would leave the Dutch house with Dutch children who had been born from the relationship with her husband. This feature continued to be a habit of the colonial people. A Nyai, although given the last name of a Dutch husband, would eventually leave the Dutch residence and become a stranger.

This Stereotype led to the understanding that an Indigenous woman, no matter how much effort she made to be a respectable woman, was still a native. All honor and dignity would relinquish right when they left their Dutch family.

\section{c. Discrimination}

Power includes the authority to control based on the authority and the thought that he has power over others. Fanon emphasized that differences in skin color and race represent a polar with eternal conflict. ${ }^{29}$ The two of them can never be equal and will always occupy the high class. Thus, the position of the natives will always be oppressed and cornered.

"You know, no Dutchman calls his native partner a wife." 30

A Dutch worker who lived in Indonesia alone would need someone to accompany him to take care of the household. Therefore, they took in a Nyai

\footnotetext{
${ }^{29}$ Fanon, Black Skin, White Masks: Kolonialisme, Rasisme, Psikologi Kulit Hitam, 26.

${ }^{30}$ Banu, Semua untuk Hindia, 22.
}

27 Banu, 39.

${ }^{28}$ Banu, 38. 
to serve themselves and helped them to take care of all their needs. A Nyai would live with a Dutchman as husband and wife. Some of them even had offspring. However, as a native, a Nyai would never gain the honor that a Dutch wife would get. A Nyai would remain a native even though she had given birth to a child from their Master.

The statement, no Dutchman calls his native partner a wife, shows the Dutch's undermining attitude towards the natives. The Dutch placed people of different races in a lowly place, even though they had been part of the family. For the Dutch, the indigenous people would never be equal to those of the same race. Bumiputera or the indigenous people were always a lowly race even though they had had relationships with Dutch people or had given birth to children from these relationships. The race was something that had its position and uncontestable. No matter how close the relationship was, it would never change their principles.

The colonialists always emphasized things related to race and skin color as something urgent, as the following excerpt shows:

"Look at your skin color, look at how you speak, are you a Dutch?"31

The excerpt above illustrates the speech acts and pressure given by a colonial nation to people of another skin color. Colonial nations always thought that their skin color and way of speaking were superior to the natives. Both of these aspects became a marker of whether someone was worthy in their eyes.

A Dutchman would only consider a wife as legal if she was of Dutch descent. Even though a Dutchman and an indigenous woman had lived under the same roof as husband and wife, that an indigenous woman received a Dutch last name, or that the native woman had given birth to a child from the Dutchman, the woman/Nyai would never be able to get the same rights as obtained by a Dutch woman when she became a wife.

A Dutchman would call the native woman by her maiden name as if they had no emotional attachment as family. In the end, every Dutchman would leave the Indigenous woman and marry a Dutch woman legally. The following excerpt depicts such a discrimination act.

"The unfortunate fate of a Nyai, that she has to leave with her children when the husband is married to a European woman." 32

A Nyai had no power nor authority to defend herself and her children in a Dutch household. When her husband married a woman of Dutch blood, the Nyai would pack her things and take her children away from home. The Nyai would raise her children away from her Dutch husband. The recognition of the relationship with the Dutchman would slowly disappear and be no longer valid. The termination of the relationship started once the Nyai stepped out of the residence of her Dutch husband.

${ }^{32}$ Banu, 20.

${ }^{31}$ Banu, 21.

OKARA: Jurnal Bahasa dan Sastra, Vol. 15, No. 1, May 2021 
In the above excerpt, it is clear that Nyai had to experience a terrible fate when her Dutch husband married a European woman. A Nyai would never be treated as a legal wife by a Dutchman. The Dutchman only used her as a temporary partner in charge of helping and taking care of his needs. The Dutchman would eventually end his relationship with the Nyai after he married a woman of European descent whom he considered more respectable than the native woman.

\section{Division and Alienation as the Impact of Racial Ethnocentrism}

Division and alienation are impacts arising from racial ethnocentrism. Through an obvious pattern, colonialism raised the superiority of the colonial nation and formed a division and alienation in the identification of the identity of the colonized society. Culture, language, and ideological history within the colonial command had become commonplace and recognized in the local culture of the colonized. ${ }^{33}$

\section{a. Division}

The division is a grouping carried out by the Dutch as a colonial practice, especially regarding the racial division. This division limits a group to optimize power over the colony based on understanding, intellectuality, and dialectics. The collection of short stories,

\footnotetext{
${ }^{33}$ Ania Loomba, Kolonialisme / Pascakolonialisme, trans. Hartono Hadikusumo (Yogyakarta: Narasi, 2016), 184-86.
}

Semua untuk Hindia, shows a division condition in the colonial environment.

The quotation below shows that a person's social class elevates because one of his family members is an employee of the colonial government.

"I am not just any woman. My father was not rich, but he was a plantation clerk. Understand?"34

His appointment as an administrative worker would differentiate his social status from all family members for colonized communities. The daughter of a plantation clerk is positioned as a character "I am not just any woman." There is a high level of dignity owned by a family who has a significant position. Not only because they were at the level of coolies, but also they were considered to have abilities in terms of executive education that all indigenous people did not understand at that time. Therefore, the data above refers to the divisional behavior, which is not only emphasized by the natives to each other but also a sign that they have a particular affinity with the colonial, which is not owned by coolies. Some women who have an interest in things the Dutch liked would receive different status, as in the following data:

"And among the many reasons I love you is because you love books and operas. Your understanding of the stage world far exceeds the white ladies." 35

"I don't deny that Imah's presence creates a new routine that feels awkward but fun. Maybe because he is quite intelligent, unlike most other male

\footnotetext{
${ }^{34}$ Banu, Semua untuk Hindia, 18.

${ }^{35}$ Banu, 23.
} 
earth women who are difficult to talk to." ${ }^{36}$

Apart from glorifying themselves and their light-skinned race, the colonial group also respected the quality of education and made it essential. These two things are what they are most proud of since they first set foot and began to colonize the archipelago.

The Dutchman, as the character "I" expressed his interest and love for the native woman who lived with him because of the native woman's interest in things that were liked by educated men from the Netherlands in general; Books and Opera.

According to them, even women from the Netherlands rarely showed interest in and understood operas and books. The perspective of the character "I" also changes towards the native woman who has been with him. The same thing was also found in the following data. The sentence that reads, "Maybe because he is pretty intelligent, unlike most other women of earth, sons who are difficult to talk to," shows that the intelligence possessed by Imah, who is a Nyai, will increase his self-worth. Intelligence for subaltern societies in the eyes of the colonials was a rarity. The Dutch would feel happy when having someone, even a woman, who has intelligence, especially if they live together and interact with each other.

These data indicate the existence of value that a person possesses even from the Nyai group when they show an interest in what the Dutch like and

${ }^{36}$ Banu, 42. respect. Under such circumstances, these indigenous women indirectly got a special place in the eyes of the Dutchmen. The same thing was often raised in discussions between Dutchmen, who both had native women as caretakers in their households.

\section{b. Alienation}

Alienation is psychological isolation that occurs as a result of racial ethnocentrism. This isolation is defined as a state apart from the great social life..$^{37}$ In general, the alienation was created by the migrants, the colonizers, to exploit the resource. The ostracism felt by the subaltern community was due to the pressure of the concept proclaimed by the superior (colonialist). Finally, the interiors understand themselves as what the Dutch have labeled them. The indigenous people then felt inferior and pushed themselves to feel continuously isolated. ${ }^{38}$

"Becoming Mrs. Van Rijk at the age of fourteen is not an easy matter. Many different ways of life are difficult for me to cross, even now." ${ }^{39}$

These women will experience confusion and generally feel isolated, especially at their very young age. An indigenous woman will always see herself as a native who is different from the men she lives with. Starting from small habits

\footnotetext{
37 Adoyi F. Onoja, "Sustaining a Tradition of Policing Through Alienation: An Assessment of Recruitment and Training in the Colonial and Postcolonial Nigeria Police," Annual Journal of African History 13, no. 1 (2017): 137-51, https://www.africabib.org/rec.php?RID=32897160X. 38 Fanon, Black Skin, White Masks: Kolonialisme, Rasisme, Psikologi Kulit Hitam, 109

${ }^{39}$ Banu, Semua untuk Hindia, 20.
} 
to lifestyle and culture, they have to deal with a genuinely isolated inner state.

"At the door, Gijs collided with Mang Acim. The swordsman hurriedly raised his prayers." 40

"Mang Acim's humility and pride in raising a child of European descent kept him at a distance from me. As if to remind that my degree is one level above him." ${ }^{41}$

Physical contact was one of the taboos for the indigenous and Dutch people. When accidental physical contact occurred, the native people would worship and show their humility before the Dutch.

Another thing that appears as alienation is the feeling of pride when raising European ancestry. With this pride, an indigenous family raising Dutch children was not the same as raising an indigenous child. They took care of these European children while still giving them honor, respecting, and consistently placing the children in the position of their masters.

"Difficult childhood. In Dutch circles, we were never fully accepted." 42

"Bastard! Everyone knows that I am not a full-blooded Dutchman. Since I was a child under the half-hearted gaze, I studied hard to accept that "civilized" circle. Learn all the things they learn."

As an adult and looking for a job, Indo descent, even though he has a Dutch face, will also find himself alienated from the European descent around him. An

\footnotetext{
${ }^{40}$ Banu, 56.

${ }^{41}$ Banu, 57.

42 Banu, 32.

${ }^{43}$ Banu, 56.
}

Indo Dutch person will find alienation addressed to him. Both division and alienation were a significant influence from colonialism and the attitudes of racial ethnocentrism that also rode it.

\section{Discussion}

The results of the colonial racial ethnocentrism analysis of Iksaka Banu's collection of stories, Semua untuk Hindia, show that racial ethnocentrism or racism in this collection of short stories appears in the form of prejudices, stereotypes, and discrimination. The formation of ethnocentric behavior is based on Western cultural concepts and views of the ideal human being, and the human position passed down from generation to generation. The racism impacted the social construction and use of authority by the Dutch in oppressing society in Indonesia.

The first point, racial prejudice, which is generally based on racial factors, emphasizes racial problems and the negative stigma embedded in people of different races from colonials. Racial prejudice, which is getting bigger and bigger, is indicated by hatred planted without a solid foundation. This perspective is preserved and embedded from generation to generation as an absolute thing in assessing other races.

The racial prejudice by the colonial nation against the indigenous people was an immoral act that cornered without any basis. Not only that, the prejudice finally spread quickly throughout other European colonials. This racial prejudice is then considered an absolute thing for natives, 
both in Indonesia and throughout their colonies in different parts of the world.

With this prejudice, natives often receive close supervision every time they work. Optimal surveillance was carried out on the natives because the fear of criminality overshadowed the colonialists, crime, and rebellion carried out by the natives who would lead to murder. Those fears made them oppress the natives and made no room to work without a guard prepared. Many supervisors and guards are prepared at various posts to reduce any circumstances that are suspected to occur. This condition is in line with Fanon's statement that being a native means having to be constantly watched and watched out for because, for the colonizers, anything could happen from the minds of the natives with all the bad possibilities that always overshadowed them. ${ }^{44}$

This prejudice applies not only to men from the subaltern population but also to women. During the colonial period, women were deliberately brought in from various regions to become plantation workers or become housekeepers in European employees' residences. These women will get the nickname "Nyai" after they live in the Netherlands. The tradition of taking an indigenous woman to become a concubine was a common practice for European men from generation to generation during colonial times, from the founding of the VOC to the time of the Dutch East Indies.

\footnotetext{
${ }^{44}$ Fanon, Black Skin, White Masks: Kolonialisme, Rasisme, Psikologi Kulit Hitam, 93.
}

The second point is stereotypes. Stereotypes usually develop early in life and are repeated and reinforced in a group. ${ }^{45}$ European colonials, especially the Dutch, instilled stereotypes when they began to colonize their other homelands. There are various kinds of stereotypes launched by the Dutch to exalt themselves further so that they become a distinguished group in their colonies, and at the same time also bring down the indigenous people with all their shortcomings, and force the natives to believe this is a determination of themselves. The collection of short stories, Semua untuk Hindia, by Iksaka Banu, reveals that there are so many stereotypes attached by the Dutch to the subaltern community, one of which is to think that natives are poor ignorant. Lack of education access in the country is one of the bases for these stereotypes that are alive and well-rooted, especially compared to Europe, which upholds education and is the pioneer of science development. Furthermore, during the colonial period in Indonesia, Europe was aggressively developing science and making great discoveries.

At another stage, Saraswati argues that light or white colors indicated a higher status throughout the colonial period. ${ }^{46}$ This condition makes natives disguised as

\footnotetext{
${ }^{45}$ Ilyas Lampe and Haslinda B. Anriani, "Stereotipe, Prasangka dan Dinamika Antaretnik," Jurnal Penelitian Pers dan Komunikasi Pembangunan 20, no. 1 (2016): 19-32, https://doi.org/10.46426/jp2kp.v20i1.42.

46 L. Ayu Saraswati, Putih: Warna Kulit, Ras, dan Kecantikan di Indonesia Transnasional (Jakarta: Marjin Kiri, 2017), 70.
} 
inlanders because of differences in treatment when they wear national attributes. Treatment in terms of law, economy, social, and respect in the colonial period has been quietly constructing the human mind since that time. Furthermore, in every colonization in various parts of the world, Europeans assumed that the indigenous races were low and primitive peoples, different from modern Europe, and had a high class. The negative representation of dark skin indicates that dark skin is valued poorly, whereas light skin is valued. Representation of hegemony elevates light skin over dark skin, even in modern times. Cultural systems from colonial times to the present time repeatedly send out the message that light skin is superior to dark skin. ${ }^{47}$ The West makes various statements about the East, legitimizes it, and creates views of them. ${ }^{48}$

The third form of ethnocentrism that is encountered is discrimination. Discrimination is nothing but a product of the past that leads to forms of action taken against vulnerable groups with various motives. The racial discrimination that arises is due to the growing stigma against a specific group and a policy issued by the authorities. Data analysis shows that the colonialists discriminated against the subaltern community. During the colonial period, the Nyai were often called Mina. Based on various sources in

\footnotetext{
${ }^{47}$ Christopher A D Charles, "Skin Bleachers' Representations of Skin Color in Jamaica," Journal of Black Studies 40, no. 2 (2009): 153-70, https://doi.org/10.1177/0021934707307852.

${ }^{48}$ Edward W. Said, Orientalism (New York: Knopf Doubleday Publishing Group, 2014), 9.
}

the form of primary manuscripts and Dutch acknowledgment deeds, the name Nyai is usually only written as Mina or Inlandesch Vrouwen. This naming is due to the existence of a clash between the natives and Europeans. There is a great chasm that forms the boundary of these two classes, which can never be crossed.

For European society, respect for equality and respect cannot be shared with other groups of nations. Dutchmen often hid the Indigenous women who had become their mistresses out of shame, even though this had been a standard behavior of European colonialists. European men at that time were not allowed to have lasting relationships with native women and only used them as a means of survival in the colonies. The reality expressed in the short story collection is in line with Irenewaty and Adhi that the European government has issued a regulation prohibiting mixed marriages because they think this is not the right way to build European civilization in the colonies. Europeans have long claimed to be superior to all kinds of races to intermarry and make other races equal was not the norm in their environment. ${ }^{49}$

In the end, when they found the wife of a fellow Dutchman, they would take her home and let the native woman and her children leave and start living alone as strangers. It was not uncommon for these indigenous women to become male servants in a joint venture with Dutch

\footnotetext{
49 Terry Irenewaty, "Eksistensi Perjuangan Wanita Masa Kolonial," ISTORIA: Jurnal Pendidikan dan IImu Sejarah 12, no. 1 (June 8, 2016): 13-27, https://doi.org/10.21831/istoria.v12i1.9541.
} 
soldiers to support themselves and their families until the end of their lives.

The grouping of natives and genuine differences in treatment is based on the political interests and ideology of the Netherlands in creating colonial freedom and continues to want to survive conquering the colonies. ${ }^{50}$ According to Goh, there were various divisions along the lines determined by the colonialists among races with specific characteristics in the colonial process. ${ }^{51}$

In the collection of short stories, Semua untuk Hindia obtained several data indicating divisions formed in the subaltern community groups. Fanon suggested that the concept undoubtedly suspects this division of indigenous intellectuality because this has become the standard and calculation for the Netherlands in general. In this collection of short stories, it is described that a native who works as a Dutch administrative interpreter will be considered noble. Not only did the clerk receive the glory, but his family was also affected. They become people who are respected and respected by other indigenous communities. Besides, the Dutch saw intellectuality as a measure of

50 Rusdian Noor Dermawan and Joko Santoso, "Mimikri dan Resistensi Pribumi Terhadap Kolonialisme dalam Novel Jejak Langkah Karya Pramoedya Ananta Toer: Tinjauan Poskolonial," Caraka 4, no. 1 (2017): 33-58, https://doi.org/10.30738/caraka.v4i1.2165.

51 Daniel P. S. Goh, "From Colonial Pluralism to Postcolonial Multiculturalism: Race, State Formation and the Question of Cultural Diversity in Malaysia and Singapore," Sociology Compass 2, no. 1 (2008): $232-52$, https://doi.org/10.1111/j.1751-9020.2007.00065.x. social status that made indigenous people respected. They become a group of people who are considered and respected to the same level as the natives in general.

The complexity possessed by the colony made a pluralistic social order bounded by social walls that separated community groups. This separation was not only based on considerations of the race but also their occupation and social status. ${ }^{52}$

The same is the case with indigenous women who are made as housekeepers by Dutchmen. From the data found in this collection of short stories, a Dutchman found an interest in indigenous women who admired things he also admired. Women with intelligence and an interest in books and operas which the Dutch glorify - made Dutchmen consider these indigenous women with a different perspective. Their gaze is no longer focused on his brown skin and wretched life but his intellect, enabling him to be a pleasant conversation partner.

These findings are supported by the results of Kauanui's research that under certain status or conditions in the colonial environment, individuals will receive different treatment from their status or characteristics. ${ }^{53}$ Thus, this native woman

52 Remco Raben, "Colonial Shorthand and Historical Knowledge: Segregation and Localisation in a Dutch Colonial Society," Journal of Modern European History 18, no. 2 (2020): 177-93, https://doi.org/10.1177/1611894420910903.

${ }^{53}$ J.Kēhaulani Kauanui, "Tracing Historical Specificity: Race and the Colonial Politics of (In)Capacity," American Quarterly 69, no. 2 (2017): 257-65, https://doi.org/10.1353/aq.2017.0019. 
became someone who was above the level of other indigenous communities and had the honor, not only in the eyes of her Dutch partner but also the people around her, both indigenous people and Europeans.

Unlike the case with the alienation or exile in the colony, racial ethnocentrism has taken complete control and created an alienation mediated by mental and psychological assaults on the racial and cultural side of the indigenous peoples. ${ }^{54}$

In the short story collection, Semua untuk Hindia, some data indicate the concept of alienation that occurred amid colonialism in the archipelago. One of these things is the psychological state of an indigenous woman married to a man from another nation. The new household conditions made him "navigate" a foreign culture that he had not yet experienced. Not only skin color, but they also have difficulty adapting to sounds, body odors, and the habits of their Dutch husbands. This situation makes most indigenous women always feel unfamiliar with their environment, and it does not last for a moment. Fanon has also mentioned that intimacy will be challenging to occur between races because their relations are too different and will impact the psychics of the natives. ${ }^{55}$ This view is difficult to

54 Canice Nwosu and Somtoo Arinze-Umobi, "Colonial Alienation and Postcolonial Marginality in African Drama: Implications for Lasting Peace in Africa," International Journal of Art and Art History 4, no. 2 (January 1, 2016): 101-28, https://doi.org/10.15640/ijaah.v4n2a8.

${ }^{55}$ Fanon, Black Skin, White Masks: Kolonialisme, Rasisme, Psikologi Kulit Hitam. change as it develops in early life and is repeated and reinforced by both parties. ${ }^{56}$

The contrast between the two cultures affects a Nyai in everyday life. As an inferior group, indigenous women will try in such a way as to balance the life patterns of their masters, who are very opposite. Moreover, they had to serve their masters in a European style, which was different from the customs they lived in native households. When an indigenous woman is appointed as a Nyai, it does not merely increase their rank than other natives. They have a lot to learn and adapt to a European civilized and very foreign environment.

The life of a Nyai is a portrait of absolute isolation. Young reveals that minorities own alienation; the unequal relations between the colonizers make them never part of the norm. ${ }^{57}$

It was also found that several families who cared for an Indo child - who came from a relationship between a Dutchman and an indigenous woman took pride in raising these children. They raised Dutch children whom their Dutch father no longer cared about with pride and respect. These indigenous families always paid tribute to European children in their families by placing themselves under these Indonesian Dutch children. They would always remind the children that the status of the natives would always be below those of European descent.

\footnotetext{
56 Lampe and Anriani, "Stereotipe, Prasangka dan Dinamika Antaretnik," 19-32.

${ }^{57}$ Robert J C Young, Postcolonialism: A Very Short Introduction, OUP Oxford (Britania Raya: OUP Oxford, 2003), 20.
} 
Indo descendants who have grown up will also feel isolated from the totok (descendant) Dutch environment. They are often treated halfheartedly because the indigenous blood that flows in their bodies. An Indo was positioned under the totok Dutch but higher than the natives. The totok Dutch would attack Indo descent as short-minded and unintelligent, even though Indo descendants pursued the same education and norms that totok Dutchmen acquired. Finally, from this labeling, the Dutch of Indo descent will continue to feel alienated because half of the indigenous blood flows in them. In the imbalance felt by Indo descendants, colonialism created a world that was always seen from a superior perspective. Those who do not purely or partially label their kind who try to enter the world will never be entirely accepted. They live by the definition coined by the dominating people. ${ }^{58}$

\section{Conclusion}

Racial ethnocentrism is an understanding that coincided with the colonial era in their colony. Racial ethnocentrism contains racial prejudice in the form of suspicion of immoral acts which the colonial accuses of indigenous people; stereotypes in the form of glorification of the colonial race over the indigenous races of the archipelago; and discrimination against indigenous people in the form of unequal treatment and

58 I. Eddy Putranto, "Dekonstruksi Identitas (Neo) Kolonial: Sebuah Agenda Teologi Postkolonial," MELINTAS 27, no. 3 (2011): 311-24, https://doi.org/10.26593/mel.v27i3.297.311-324. attitudes and actions that marginalize natives.

This form of racial ethnocentrism impacts two types of impacts: varied divisions or groupings in the colony with the characteristic lines defined by the Dutch and alienation or isolation, making the indigenous people feel isolated and accepting how the colonialists represent them. The form (racial prejudice, stereotypes, discrimination) and impact (division and alienation) of this racial ethnocentrism are fully and clearly expressed in the collection of short stories Semua untuk Hindia.

\section{References}

Bahardur, Iswadi. "Pribumi Subaltern dalam Novel-Novel Indonesia Pascakolonial." Gramatika: Jurnal Penelitian Bahasa dan Sastra 4, no. 1 (2017): 89-100. https://doi.org/10.22202/jg.2017.v3i1 .1876 .

Banu, Iksaka. Semua untuk Hindia. Jakarta: Kepustakaan Populer Gramedia, 2018.

Brown, Rupert. Prejudice: Its Social Psychology. London: WileyBlackwell, 2011.

Carignan, Nicole, Michael Sanders, and Roland G. Pourdavood. "Racism and Ethnocentrism: Social Representations of Preservice Teachers in the Context of Multiand Intercultural Education." The International Journal of Qualitative Methods 4, no. 3 (2005): 1-19. https://doi.org/10.1177/1609406905 00400301.

Charles, Christopher A D. "Skin Bleachers' Representations of Skin Color in Jamaica." Journal of Black Studies 40, no. 2 (2009): 153-70. https://doi.org/10.1177/0021934707 307852. 
Cunningham, William A., John B. Nezlek, and Mahzarin R. Banaji. "Implicit and Explicit Ethnocentrism: Revisiting the Ideologies of Prejudice." Personality and Social Psychology Bulletin 30, no. 10 (2004): 1332-46. https://doi.org/10.1177/0146167204 264654.

Dermawan, Rusdian Noor, and Joko Santoso. "Mimikri dan Resistensi Pribumi Terhadap Kolonialisme dalam Novel Jejak Langkah Karya Pramoedya Ananta Toer: Tinjauan Poskolonial." Caraka 4, no. 1 (2017): 33-58. https://doi.org/10.30738/caraka.v4i1. 2165 .

Fanon, Frantz. Black Skin, White Masks: Kolonialisme, Rasisme, Psikologi Kulit Hitam. Translated by Harris $\mathrm{H}$ Setiadji. Yogyakarta: Jalasutra, 2016.

Goh, Daniel P. S. "From Colonial Pluralism to Postcolonial Multiculturalism: Race, State Formation and the Question of Cultural Diversity in Malaysia and Singapore." Sociology Compass 2, no. 1 (2008): 232-52. https://doi.org/10.1111/j.17519020.2007.00065.x.

Hall, Schekeva. "The Role of Racial Socialization and Ethnocentrism in the Racial Identity Development of Second-Generation Black West Indian Americans." Columbia University, 2012. https://academiccommons.columbia. edu/doi/10.7916/D8RVOVTK.

Irenewaty, Terry. "Eksistensi Perjuangan Wanita Masa Kolonial." ISTORIA: Jurnal Pendidikan dan IImu Sejarah 12, no. 1 (2016): 13-27. https://doi.org/10.21831/istoria.v12i1 .9541 .

Kauanui, J.Kēhaulani. "Tracing Historical Specificity: Race and the Colonial Politics of (In) Capacity." American Quarterly 69, no. 2 (2017): 257-65. https://doi.org/10.1353/aq.2017.0019.
Lake, Marilyn. "Equality and Exclusion: The Racial Constitution of Colonial Liberalism." Thesis Eleven 95, no. 1 (2008): 20-32. https://doi.org/10.1177/0725513608 095798.

Lampe, Ilyas, and Haslinda B. Anriani. "Stereotipe, Prasangka dan Dinamika Antaretnik." Jurnal Penelitian Pers dan Komunikasi Pembangunan 20, no. 1 (2016): 1932.

https://doi.org/10.46426/jp2kp.v20i1. 42.

Loomba, Ania. Kolonialisme / Pascakolonialisme. Translated by Hartono Hadikusumo. Yogyakarta: Narasi, 2016.

Martin, James G. "Racial Ethnocentrism and Judgment of Beauty." The Journal of Social Psychology 63, no. 1 (1964): 59-63. https://doi.org/10.1080/00224545.19 64.9922213.

Mulyana, Deddy, and Jalaluddin Rakhmat. Komunikasi Antar Budaya: Panduan Berkomunikasi dengan OrangOrang Berbeda. Bandung: Remaja Rosdakarya, 2010.

Nensilianti, and Dian Hezedila Sharon. "Novel Entitle Student Hidjo by Mas Marco Kartodikromo: Postcolonial Study." In International Conference on Natural and Social Sciences (ICONSS) Proceeding Series 1, 2:375-81, 2019. https://doi.org/10.30605/iconss.57.

Nurhuda, Taguh Alif, and Herman $J$ Waluyo Suwitno. "Pemanfaatan Sastra Sebagai Bahan Ajar Pengajaran BIPA." In The 1st Education and Language International Conference Proceedings Center for International Language Development of Unissula. Halaman, 864-69. The 1st Education and Language International Conference Proceedings Center for International Language Development of Unissula, 2017. 
Nwosu, Canice, and Somtoo ArinzeUmobi. "Colonial Alienation and Postcolonial Marginality in African Drama: Implications for Lasting Peace in Africa." International Journal of Art and Art History 4, no. 2 (2016): 101-28. https://doi.org/10.15640/ijaah.v4n2a 8.

Onoja, Adoyi F. "Sustaining a Tradition of Policing Through Alienation: An Assessment of Recruitment and Training in the Colonial and Postcolonial Nigeria Police." Annual Journal of African History 13, no. 1 (2017): 137-51. https://www.africabib.org/rec.php?RI $D=32897160 X$.

Permatasari, Riana. "The Negative Effects of Ethnocentrism in My Big Fat Greek Wedding Movie." Jurnal Penelitian Humaniora 20, no. 2 (2019): 89-97. https://doi.org/10.23917/humaniora. v20i2.7401.

Putranto, I. Eddy. "Dekonstruksi Identitas (Neo) Kolonial: Sebuah Agenda Teologi Postkolonial." MELINTAS 27, no. 3 (2011): 311-24. https://doi.org/10.26593/mel.v27i3.2 97.311-324.

Raben, Remco. "Colonial Shorthand and Historical Knowledge: Segregation and Localisation in a Dutch Colonial Society." Journal of Modern European History 18, no. 2 (2020): 177-93. https://doi.org/10.1177/1611894420 910903.

Said, Edward W. Orientalism. New York: Knopf Doubleday Publishing Group, 2014.

Saraswati, L. Ayu. Putih: Warna Kulit, Ras, dan Kecantikan di Indonesia Transnasional. Jakarta: Marjin Kiri, 2017.
Sulistianawati. "Pribumi Subaltern dalam Novel Lampuki Karya Arafat Nur (Kajian Poskolonial Gayatri C. Spivak)." Stilistika: Jurnal Pendidikan Bahasa dan Sastra 13, no. 2 (2020): 155-67. https://doi.org/10.30651/st.v13i2.453 3.

Sutrisno, Mudji. Cultural Studies: Tantangan bagi Teori-Teori Besar Kebudayaan. Depok: Penerbit Koekoesan, 2011.

Young, Robert J C. Postcolonialism: $A$ Very Short Introduction. OUP Oxford. Britania Raya: OUP Oxford, 2003. 